\title{
Original
}

\section{Association of vitamin D-related gene polymorphisms with manifestation of vitamin D deficiency in children}

\author{
Sachiko Kitanaka ${ }^{1)}$, Tsuyoshi Isojima ${ }^{1)}$, Minako Takaki ${ }^{1)}$, Chikahiko Numakura ${ }^{2)}$, Kiyoshi Hayasaka ${ }^{2)}$ and \\ Takashi Igarashi ${ }^{1)}$ \\ 1) Department of Pediatrics, Graduate School of Medicine, The University of Tokyo, Tokyo 113-8655, Japan \\ 2) Department of Pediatrics, Yamagata University School of Medicine, Yamagata 990-9585, Japan
}

\begin{abstract}
The prevalence of vitamin D deficiency, presenting as hypocalcemic seizures or rickets in children, is increasing worldwide due to insufficient vitamin D intake and lack of exposure to sunshine. However, considering that relatively few children with low 25-hydroxyvitamin D [25(OH)D] levels manifest symptoms, it is possible that genetic factors may predispose individuals to vitamin D deficiency. Recent twin studies have reported that the level of serum of $25(\mathrm{OH}) \mathrm{D}$ is influenced by genetic factors. In addition, genome-wide association studies and candidate gene studies have revealed that several vitamin D-related genes, including VDR, GC, NADSYN1, CYP2R1, CYP24A1, CYP27B1, and C10orf88 contribute to variations in serum $25(\mathrm{OH}) \mathrm{D}$ levels. To investigate whether genetic predisposition contributes to vitamin $\mathrm{D}$ deficiency, we analyzed polymorphisms in vitamin D-related genes in 30 Japanese patients with vitamin D deficiency presenting at less than 4 years of age, along with 66 controls. A $\chi^{2}$ test showed that the genotype frequencies of Bsm I polymorphism in $V D R$ and rs10898191 in NADSYN1 were significantly different between the two groups. The allele frequencies of BsmI, ApaI, TaqI in VDR, rs10898191 in NADSYN1, and rs705117 in GC were also significantly different. In particular, the frequency of the BAtS haplotype in $V D R$ was significantly increased in the patient group relative to controls $(p=0.0014$; odds ratio, 5.61; 95\% confidence interval 1.92 - 16.40). Although this is a small study, our findings suggest that $V D R$, NADSYN1, and GC polymorphisms may be linked to the manifestation of vitamin D deficiency in Japanese children.
\end{abstract}

Key words: Vitamin D deficiency, Polymorphism, VDR gene, GC gene, NADSYN1 gene

THE PREVALENCE of vitamin D deficiency, presenting as hypocalcemic seizures or rickets in children, is increasing worldwide due to insufficient intake of vitamin D, particularly by breast-feeding, and lack of exposure to sunshine. Vitamin D deficiency is most common in dark-skinned races, but it is also common in yellow-skinned races, including the Japanese [1-3].

Although a large number of breast-fed infants have low serum 25-hydroxyvitamin D [25(OH)D] levels, only a few of them manifest overt symptoms of vitamin D deficiency. Moreover, obvious environmental factors such as lack of exposure to sunshine or inadequate vitamin D intake are not associated with vitamin D deficiency in some patients. Therefore, we speculated

Submitted Apr. 12, 2012; Accepted Jun. 26, 2012 as EJ12-0143 Released online in J-STAGE as advance publication Jul. 8, 2012

Correspondence to: Sachiko Kitanaka, Department of Pediatrics, Graduate School of Medicine, The University of Tokyo, 7-3-1 Hongo, Bunkyo-ku, Tokyo, 113-8655, Japan.

E-mail: sachi-tky@umin.ac.jp that genetic predisposition may influence the manifestation of vitamin $\mathrm{D}$ deficiency.

Recent twin studies have reported that the level of serum of $25(\mathrm{OH}) \mathrm{D}$ is influenced by genetic factors [4-6]. The largest study reported that $70 \%$ of the variation in serum $25(\mathrm{OH}) \mathrm{D}$ levels during the winter is due to genetic factors. To date, many studies have reported the association of circulating $25(\mathrm{OH}) \mathrm{D}$ levels and polymorphisms in the genes encoding vitamin D-binding protein $(G C)$, vitamin $\mathrm{D}$ receptor $(V D R)$, vitamin D 1 $\alpha$-hydroxylase $(C Y P 27 B 1)$, 24-hydroxylase (CYP24A1), and 25-hydroxylase (CYP2R1) by candidate gene analysis [7-10]. Moreover, recent genome-wide association studies (GWAS) have shown that several vitamin D-related genes, including NAD synthetase (NADSYN1, linked to 7-dehydrocholesterol reductase [DHCR7]), GC, CYP2R1,CYP24A1, and C10orf88, contribute to variations in serum $25(\mathrm{OH}) \mathrm{D}$ levels $[11,12]$, which association was replicated by others $[13,14]$. However, few studies have investi- 
gated an association between gene polymorphisms and manifestation of vitamin D deficiency.

In this study, we analyzed previously reported vitamin D-related polymorphisms in Japanese children manifesting vitamin $\mathrm{D}$ deficiency.

\section{Subjects and Methods}

\section{Subjects}

Thirty Japanese patients manifesting vitamin D deficiency were included in the study. Selection criteria for patient participation in the study were as follows: vitamin $\mathrm{D}$ deficiency presenting at less than 4 years of age, vitamin D deficiency presenting with either overt rickets or hypocalcemic seizures, taking no medication that interferes with vitamin D metabolism, and having no history of rickets of prematurity. Clinical diagnosis of vitamin D deficiency was made by assessing hypocalcemia and/ or hypophosphatemia, high serum alkaline phosphatase (ALP) levels, typical findings of rickets on bone roentgenogram, low circulating 25(OH)D levels, and elevated serum parathyroid hormone (PTH) levels. The control group consisted of 66 healthy Japanese volunteers with no history of rickets or hypocalcemic seizures.

The study protocol was approved by the ethical committees of the University of Tokyo and Yamagata University and was performed according to the Declaration of Helsinki. Written informed consent for DNA analyses was obtained from the parents of patients and healthy individuals.

\section{Gene analysis}

We selected polymorphisms that have been reported to be associated with serum $25(\mathrm{OH}) \mathrm{D}$ levels in either GWAS or candidate gene studies [8, 9, 11, 12, 15-20]. Well-known VDR polymorphisms reported to be associated with bone mineral density and several vitamin D-related diseases were also included [21-23]. Genomic DNA was isolated from peripheral white blood cells, and PCR-restriction fragment length polymorphism was performed for VDR BsmI, ApaI, and TaqI (rs1544410, rs7975232, and rs731236, respectively) as previously reported [24]. $V D R$ polyA polymorphism (rs17878969) was analyzed by GeneScan as previously reported [23], and based on the number of consecutive adenines (As) within the repeat sequence, polymorphism was classified as "L" (long), with more than $17 \mathrm{As}$, or "S" (short), with 17 or less As. PCR-direct sequencing was performed for other polymorphisms (VDR FokI: rs10735810, CYP27B1: rs10877012; CYP2R1: rs10741657, rs2060793; CYP24A1: rs6013897; GC: rs4588, rs7041, rs2282679, rs1155563; NADSYN1: rs12785878, rs3829251; C10orf88: rs6599638), and were analyzed along with the neighboring single nucleotide polymorphisms (SNPs) (GC: rs705117; NADSYN1: rs10898191). The sequences of PCR primers and the PCR conditions will be provided on request.

\section{Statistical analysis}

Values are expressed as mean $\pm \mathrm{SD}$. The goodness of fit to the Hardy-Weinberg equilibrium was determined by comparing the calculated expected frequency of each genotype with the observed value using a $\chi^{2}$ test. Comparisons of genotype frequency and allele frequency between patients and control subjects were performed using a $\chi^{2}$ test for $2 \times 2$ or $2 \times 3$ tables, with Yates' correction if necessary. Genotype and the clinical data were compared using a Student's $t$-test. Statistical significance was set at $p<0.05$.

\section{Results}

\section{SNP analysis}

The characteristics of the patient group were summarized in Table 1. Seven patients had no risk factors other than breast-feeding. None of the patients had

Table 1 Characteristics of patients

\begin{tabular}{llc}
\hline & & Total $(\mathrm{n}=30)$ \\
\hline Age at onset (years)* & & $1.48 \pm 0.76$ \\
Male : female & & $26: 4$ \\
Feeding in infancy & breast & 25 \\
& mixed & 1 \\
& unknown & 4 \\
Food restrictions/unbalanced diet & yes & 18 \\
& no & 12 \\
Low sunlight exposure & yes & 5 \\
& no & 25 \\
Serum 25(OH)D (ng/mL)** & & median $8(<5$ to 22.9$)$ \\
Serum ALP (IU/L)* & & $2,394 \pm 699$ \\
Serum Ca (mg/dL)* & & $8.13 \pm 1.61$ \\
Serum iP (mg/dL)* & & $3.84 \pm 1.14$ \\
Serum intact PTH $(\mathrm{pg} / \mathrm{mL})^{*}$ & & $272 \pm 165$ \\
\hline
\end{tabular}

25(OH)D, 25-hydroxyvitamin D; ALP, alkaline phosphatase; $\mathrm{Ca}$, calcium; iP, inorganic phosphate; *Mean $\pm \mathrm{SD} * *$ Serum $25(\mathrm{OH}) \mathrm{D}$ assay method was Diasorin radioimmunoassay, except for one with Diasorin Liaison Total Chemiluminescence immunoassay $(7.82 \mathrm{ng} / \mathrm{ml})$, and three with competitive proteinbinding assay $(11.8,20.7,22.9 \mathrm{ng} / \mathrm{mL})$. 
a mutation in the $C Y P 2 R 1$ coding region (enzyme for vitamin D 25-hydroxylation) [25].

The distribution of the analyzed SNPs in the control group was in accordance with the assumption of Hardy-Weinberg equilibrium. We compared genotype and allele frequencies between patients and controls. Genotype frequencies of $B s m \mathrm{I}$ polymorphism in $V D R$ and rs10898191 in NADSYN1 were significantly different between the patient and control groups (Table 2). The allele frequencies of the B allele of $B s m \mathrm{I}, \mathrm{A}$ allele of $A p a \mathrm{I}$, and $\mathrm{t}$ allele of TaqI, all minor alleles of $V D R$, were significantly increased in the patient group $(p<0.05$; Table 3$)$. For other genes, the minor alleles of rs10898191 in NADSYN1 and rs705117 in $G C$ were significantly increased in the patient group $(p<0.05)$.

\section{Haplotype analysis}

BsmI, ApaI, TaqI, and polyA polymorphisms in VDR lie near or within the last exon and are in linkage disequilibrium [26]. Because all alleles with increased frequency in the patients were minor alleles, we analyzed the frequency of the minor BAtS haplotype between the two groups and discovered a significantly increased frequency in the patient group relative to the control group $(p=0.0014$; odds ratio, $5.61 ; 95 \%$ confidence interval 1.92 - 16.40; Table 4).

\section{Association of genotype and clinical features}

We compared age at onset, presence of risk factors other than breast-feeding, serum calcium levels, serum 25(OH)D levels, and serum 1,25-dihydroxyvitamin $\mathrm{D}\left[1,25(\mathrm{OH})_{2} \mathrm{D}\right]$ levels between patients with or without the BAtS haplotype or the high-risk alleles of rs 10898191 and rs 705117. However, we found no significant differences in any of these parameters (data not shown).

\section{Discussion}

We observed that polymorphisms in $V D R, G C$, and NADSYN1 were associated with vitamin D deficiency. Moreover, patients harboring the minor BAtS haplotype had a 5.6-fold increased risk of vitamin D deficiency. The minor allele frequency of each $V D R$ polymorphism in the control group was comparable to that in other Japanese controls, indicating no bias in the selection of the control group [27-29]. rs10898191 in NADSYN1 is 42 bp away from rs3829251, which has been reported to be associated with reduced $25(\mathrm{OH})$
D levels in a GWAS [11]. Moreover, the association of rs3829251 with reduced 25(OH)D levels was also found in a Chinese cohort [14]. rs705117 in GC is $268 \mathrm{bp}$ away from rs 2282679 , which is associated with reduced 25(OH)D levels in both Caucasians and Chinese $[11,12,14]$. We believe that polymorphisms in these genes are also associated with low 25(OH)D levels in the Japanese population.

The influence of environmental factors such as vitamin D intake or ultraviolet radiation levels on other diseases have been reported to differ with $V D R$ genotype $[23,30]$. Individuals with $V D R$ minor genotypes are more sensitive to vitamin $\mathrm{D}$ administration and exhibit low calcium absorption [31, 32]. Moreover, $V D R$ minor alleles have been reported to alter $V D R$ function or expression [33, 34]. Otherwise, VDRmediated regulation of 24-hydroxylase may be modified by altered VDR function, thereby influencing the degradation of $25(\mathrm{OH}) \mathrm{D}$ and $1,25(\mathrm{OH})_{2} \mathrm{D}$. Taken our results together, we believe that children with $V D R$ minor haplotype may be more influenced by vitamin D insufficiency and more likely to manifest overt rickets or hypocalcemia. This genetic predisposition may explain why only some of the thousands of children with low 25(OH)D levels manifest symptoms, while the majority are symptom free.

So far, many reports have shown an association between $V D R$ polymorphisms and bone mineral density or osteoporosis [22, 35]. In particular, BsmI, ApaI, $T a q \mathrm{I}$, and polyA polymorphisms around the last exon are in linkage disequilibrium and have been extensively investigated. The two most relevant findings among several reports and a meta-analysis are that 1) the B allele of $B s m \mathrm{I}$ is related to reduced bone mineral density and 2) Bat and BAt haplotypes are significantly associated with osteoporosis $[36,37]$. The risk associated with a minor haplotype in reducing positive action of vitamin $\mathrm{D}$ is consistent with the results of this study.

Numerous reports indicate an association between $V D R$ polymorphisms and diseases such as cancer and autoimmune diseases [22]. In particular, minor alleles around the last exon of $V D R$ have been reported to be associated with type 1 diabetes, multiple sclerosis, and prostate cancer in Japanese patients [27-29, 38]. Vitamin D insufficiency is a risk factor for all these diseases [39]. Considering our results together, we believe that individuals with these minor alleles are at increased risk of the diseases because they are more influenced by vitamin D insufficiency. However, 
Table 2 Genotype of single nucleotide polymorphisms analyzed in patients with vitamin D deficiency $(\mathrm{n}=30)$ and controls $(\mathrm{n}=66)$

\begin{tabular}{|c|c|c|c|c|c|c|}
\hline Gene & SNP & Group & & Genotype & & $p$-value \\
\hline \multirow[t]{15}{*}{$V D R$} & rs10735810 & & cc (FF) & ct (Ff) & $\mathrm{tt}(\mathrm{ff})$ & \\
\hline & (FokI) & Patient & 15 & 12 & 3 & 0.889 \\
\hline & & Control & 28 & 28 & 10 & \\
\hline & rs 1544410 & & $\operatorname{gg}(\mathrm{bb})$ & ag (bB) & aa $(\mathrm{BB})$ & \\
\hline & $(B s m \mathrm{I})$ & Patient & 17 & 13 & 0 & $0.027^{*}$ \\
\hline & & Control & 54 & 10 & 2 & \\
\hline & rs7975232 & & gg (aa) & $\operatorname{tg}(\mathrm{aA})$ & $\mathrm{tt}(\mathrm{AA})$ & \\
\hline & (ApaI) & Patient & 6 & 19 & 5 & 0.052 \\
\hline & & Control & 32 & 25 & 9 & \\
\hline & rs731236 & & $\mathrm{tt}(\mathrm{TT})$ & tc $(\mathrm{Tt})$ & $\mathrm{cc}(\mathrm{tt})$ & \\
\hline & $(T a q \mathrm{I})$ & Patient & 17 & 13 & 0 & 0.063 \\
\hline & & Control & 53 & 12 & 1 & \\
\hline & rs17878969 & & LL & LS & SS & \\
\hline & (polyA) & Patient & 18 & 12 & 0 & 0.083 \\
\hline & & Control & 54 & 11 & 1 & \\
\hline \multirow[t]{3}{*}{ CYP27B1 } & rs 10877012 & & aа & $\mathrm{ac}$ & $\mathrm{cc}$ & \\
\hline & & Patient & 17 & 11 & 2 & 0.892 \\
\hline & & Control & 41 & 19 & 6 & \\
\hline \multirow[t]{6}{*}{$C Y P 2 R 1$} & rs 10741657 & & aa & ag & gg & \\
\hline & & Patient & 8 & 11 & 11 & 0.889 \\
\hline & & Control & 17 & 29 & 20 & \\
\hline & rs2060793 & & aa & ag & gg & \\
\hline & & Patient & 5 & 13 & 12 & 0.980 \\
\hline & & Control & 9 & 32 & 25 & \\
\hline \multirow[t]{3}{*}{ CYP24A1 } & rs6013897 & & $\mathrm{tt}$ & ta & aa & \\
\hline & & Patient & 23 & 7 & 0 & 0.415 \\
\hline & & Control & 59 & 7 & 0 & \\
\hline \multirow[t]{15}{*}{$G C$} & rs 4588 & & $\mathrm{cc}$ & $\mathrm{ca}$ & aa & \\
\hline & & Patient & 19 & 10 & 1 & 0.993 \\
\hline & & Control & 41 & 21 & 4 & \\
\hline & rs 7041 & & $\mathrm{tt}$ & gt & gg & \\
\hline & & Patient & 17 & 12 & 1 & 0.983 \\
\hline & & Control & 34 & 28 & 4 & \\
\hline & rs 2282679 & & aa & $\mathrm{ac}$ & $\mathrm{cc}$ & \\
\hline & & Patient & 15 & 12 & 3 & 0.814 \\
\hline & & Control & 40 & 22 & 4 & \\
\hline & rs705117 & & gg & ag & aa & \\
\hline & & Patient & 7 & 12 & 11 & 0.075 \\
\hline & & Control & 24 & 33 & 9 & \\
\hline & rs1155563 & & $\mathrm{tt}$ & ct & $\mathrm{cc}$ & \\
\hline & & Patient & 10 & 17 & 3 & 0.925 \\
\hline & & Control & 19 & 37 & 10 & \\
\hline \multirow[t]{9}{*}{ NADSYN1 } & rs 12785878 & & gg & gt & $\mathrm{tt}$ & \\
\hline & & Patient & 13 & 13 & 4 & 0.982 \\
\hline & & Control & 30 & 28 & 8 & \\
\hline & rs3829251 & & gg & ag & aa & \\
\hline & & Patient & 7 & 18 & 5 & 0.420 \\
\hline & & Control & 26 & 30 & 10 & \\
\hline & rs10898191 & & gg & ag & aa & \\
\hline & & Patient & ${ }^{85} 4$ & 20 & 6 & $0.043^{*}$ \\
\hline & & Control & 28 & 29 & 9 & \\
\hline \multirow[t]{3}{*}{ c10orf88 } & rs659938 & & gg & ag & aa & \\
\hline & & Patient & 7 & 8 & 15 & 0.475 \\
\hline & & Control & 10 & 28 & 28 & \\
\hline
\end{tabular}


Table 3 Allele frequencies of the single nucleotide polymorphisms analyzed in patients with vitamin D deficiency (n $=30)$ and controls $(\mathrm{n}=66)$

\begin{tabular}{|c|c|c|c|c|c|c|}
\hline \multirow{2}{*}{$\begin{array}{l}\text { Gene } \\
V D R\end{array}$} & \multirow{3}{*}{$\begin{array}{c}\text { SNP } \\
\text { rs } 10735810 \\
(\text { Fok })\end{array}$} & \multirow{4}{*}{$\begin{array}{l}\text { Group } \\
\\
\text { Patient } \\
\text { Control }\end{array}$} & \multicolumn{2}{|c|}{ Allelic frequency } & \multirow{3}{*}{$\frac{p \text {-value }}{0.390}$} & \multirow{3}{*}{$\frac{\mathrm{OR}(95 \% \mathrm{CI})}{0.75(0.39-1.45)}$} \\
\hline & & & $\mathrm{c}(\mathrm{F})$ & $t(f)$ & & \\
\hline & & & 0.70 & 0.30 & & \\
\hline & & & 0.64 & 0.36 & & \\
\hline & rs1544410 & & g (b) & a (B) & & \\
\hline & (BsmI) & Patient & 0.78 & 0.22 & $0.041^{*}$ & $2.33(1.02-5.33)$ \\
\hline & & Control & 0.89 & 0.11 & & \\
\hline & rs7975232 & & g (a) & $\mathrm{t}(\mathrm{A})$ & & \\
\hline & (ApaI) & Patient & 0.52 & 0.48 & $0.037^{*}$ & $1.94(1.04-3.61)$ \\
\hline & & Control & 0.67 & 0.33 & & \\
\hline & rs731236 & & $t(T)$ & $c(t)$ & & \\
\hline & $(\operatorname{Taq} \mathrm{I})$ & Patient & 0.78 & 0.22 & $0.041^{*}$ & $2.33(1.02-5.33)$ \\
\hline & & Control & 0.89 & 0.11 & & \\
\hline & rs17878969 & & $\mathrm{L}$ & $\mathrm{S}$ & & \\
\hline & (polyA) & Patient & 0.80 & 0.20 & 0.053 & $2.29(0.97-5.37)$ \\
\hline & & Control & 0.90 & 0.10 & & \\
\hline \multirow[t]{3}{*}{ CYP27B1 } & rs10877012 & & $\mathrm{a}$ & c & & \\
\hline & & Patient & 0.75 & 0.25 & 0.819 & $1.09(0.53-2.21)$ \\
\hline & & Control & 0.77 & 0.23 & & \\
\hline \multirow{9}{*}{$C Y P 2 R 1$} & rs12794714 & & $\mathrm{c}$ & $\mathrm{t}$ & & \\
\hline & & Patient & 0.55 & 0.45 & 0.738 & $1.11(0.60-2.05)$ \\
\hline & & Control & 0.58 & 0.42 & & \\
\hline & rs10741657 & & $\mathrm{g}$ & $\mathrm{a}$ & & \\
\hline & & Patient & 0.55 & 0.45 & 0.725 & $0.90(0.49-1.65)$ \\
\hline & & Control & 0.52 & 0.48 & & \\
\hline & rs2060793 & & g & $\mathrm{a}$ & & \\
\hline & & Patient & 0.62 & 0.38 & 0.952 & $1.02(0.54-1.91)$ \\
\hline & & Control & 0.62 & 0.38 & & \\
\hline \multirow[t]{3}{*}{ CYP24A1 } & rs6013897 & & $\mathrm{t}$ & $\mathrm{a}$ & & \\
\hline & & Patient & 0.88 & 0.12 & 0.203 & $2.36(0.79-7.01)$ \\
\hline & & Control & 0.95 & 0.05 & & \\
\hline \multirow[t]{18}{*}{$G C$} & rs 4588 & & c & $\mathrm{a}$ & & \\
\hline & & Patient & 0.80 & 0.20 & 0.758 & $0.89(0.42-1.89)$ \\
\hline & & Control & 0.78 & 0.22 & & \\
\hline & rs 7041 & & $\mathrm{t}$ & g & & \\
\hline & & Patient & 0.77 & 0.23 & 0.564 & $0.81(0.40-1.65)$ \\
\hline & & Control & 0.73 & 0.27 & & \\
\hline & rs2282679 & & $\mathrm{a}$ & c & & \\
\hline & & Patient & 0.70 & 0.30 & 0.280 & $1.46(1.73-2.89)$ \\
\hline & & Control & 0.77 & 0.23 & & \\
\hline & rs2282680 & & $\mathrm{g}$ & $\mathrm{a}$ & & \\
\hline & & Patient & 0.77 & 0.23 & 0.833 & $1.08(0.52-2.24)$ \\
\hline & & Control & 0.78 & 0.22 & & \\
\hline & rs705117 & & $\mathrm{g}$ & $\mathrm{a}$ & & \\
\hline & & Patient & 0.43 & 0.57 & $0.020^{*}$ & $2.07(1.12-3.86)$ \\
\hline & & Control & 0.61 & 0.39 & & \\
\hline & rs 1155563 & & $\mathrm{t}$ & $\mathrm{c}$ & & \\
\hline & & Patient & 0.62 & 0.38 & 0.527 & $0.82(0.44-2.05)$ \\
\hline & & Control & 0.57 & 0.43 & & \\
\hline \multirow[t]{12}{*}{ NADSYN1 } & rs 12785878 & & $\mathrm{~g}$ & $\mathrm{t}$ & & \\
\hline & & Patient & 0.65 & 0.35 & 0.821 & $1.08(0.57-2.05)$ \\
\hline & & Control & 0.67 & 0.33 & & \\
\hline & rs3829251 & & $\mathrm{g}$ & $\mathrm{a}$ & & \\
\hline & & Patient & 0.53 & 0.47 & 0.250 & $1.44(0.77-2.66)$ \\
\hline & & Control & 0.62 & 0.38 & & \\
\hline & rs10898191 & & $\mathrm{g}$ & $\mathrm{a}$ & & \\
\hline & & Patient & 0.47 & 0.53 & $0.021^{*}$ & $2.07(1.11-3.84)$ \\
\hline & & Control & 0.64 & 0.36 & & \\
\hline & rs71473837 & & $\mathrm{a}$ & $\mathrm{g}$ & & \\
\hline & & Patient & 0.93 & 0.07 & 0.786 & $0.98(0.29-3.30)$ \\
\hline & & Control & 0.93 & 0.07 & & \\
\hline \multirow[t]{3}{*}{ c10orf88 } & rs659938 & & $\mathrm{a}$ & $\mathrm{g}$ & & \\
\hline & & Patient & 0.63 & 0.37 & 0.903 & $1.01(0.54-1.91)$ \\
\hline & & Control & 0.64 & 0.36 & & \\
\hline
\end{tabular}


Table 4 BAtS haplotype in VDR of patients with vitamin D deficiency $(n=30)$ and controls $(n=66)$

\begin{tabular}{lcccc}
\hline Group & BAtS - & BAtS + & $p$-value & OR (95\% CI) \\
\hline Patient & 18 & 12 & $0.0014^{*}$ & $5.61(1.92-16.40)$ \\
Control & 59 & 7 & & \\
${ }^{*} p<0.05$, OR, odds ratio; $95 \%$ CI, $95 \%$ confidence interval
\end{tabular}

larger studies are necessary to confirm the relationship between the risk of vitamin D deficiency in childhood and other diseases related to vitamin D insufficiency.

Some studies investigating the genetic factors involved in vitamin D-deficient rickets identified association with VDR ApaI and FokI polymorphisms, whereas others found no association with BsmI , ApaI, and TaqI polymorphisms [40-43]. Additionally, an almost significant degree of association has been reported between ApaI polymorphism and osteomalacia [44]. Although these associations are not identical to our data, probably because of differences in ethnicity, we believe that $V D R$ is most likely to be one of the disease susceptibility genes for vitamin D deficiency.

One of the limitations of our study was the relatively small sample size. Except for the haplotype analysis, no disease associations with polymorphisms reached a level of significance after correction for multiple testing. Another limitation was the lack of a comprehensive genetic analysis, which needs a far larger sample cohort. Moreover, we did not identify any clinical differences between patients with and without risk-associated haplotypes. This may have been because our group included only young children, and further analyses including patients of different ages may be necessary to clarify this point.

Recently, vitamin D supplementation has been rec- ommended for all infants, especially those who are breast-fed [45]. However, some children are genetically sensitive to vitamin D supplementation and may become hypercalcemic after this treatment [46]. Together with our finding of genetic predisposition for vitamin D deficiency, we believe that genetic factors should be taken into account in the future design of personalized supplementation. In addition, large studies on patients with overt symptoms of vitamin D deficiency are necessary.

In summary, although only a limited number of subjects were investigated, we found an association of $V D R, G C$, and NADSYN1 polymorphisms with vitamin D deficiency. Considering that only some children with reduced serum $25(\mathrm{OH}) \mathrm{D}$ levels manifest overt symptoms of vitamin D deficiency, our findings suggest that polymorphisms of these genes may be linked to the manifestation of vitamin D deficiency in Japanese children.

\section{Conflict of Interest}

All authors have no conflicts of interest.

\section{Acknowledgments}

This study was supported by grants from the Ministry of Education, Culture, Sports, Science and Technology $(20591215,23591489)$, and by a grant from the Morinaga Hoshikai of Japan. We thank Drs. Y. Okada, T. Tajima, K. Goji, T. Momoi, I. Fujiwara, Y. Akazawa, K. Kudo, R. Ooyanagi, T. Sato, H. Inada, K. Nagasaki, K. Ozono, and S. Amemiya for providing samples and data of the cases, Dr. H. Ohtsu for helpful comments.

\section{References}

1. Akazawa Y, Shiohara M, Amano Y, Uchida N, Nakamura S, et al. (2010) The clinical characteristics of vitamin D deficiency in childhood: a systematic literature review of Japanese patients. $J$ Pediatr Endocrinol Metab 23:675-684.

2. Nishikura K, Kano K, Arisaka O, Morishima N (2002) Case of incidentally diagnosed vitamin D deficiency rickets: a review of literature from Japan and a proposal for reintroduction of vitamin $\mathrm{D}_{2}$. Pediatr Int 44:179182 .
3. Weisberg P, Scanlon KS, Li R, Cogswell ME (2004) Nutritional rickets among children in the United States: review of cases reported between 1986 and 2003. Am J Clin Nutr 80: 1697S-1705S.

4. Karohl C, Su S, Kumari M, Tangpricha V, Veledar E, et al. (2010) Heritability and seasonal variability of vitamin D concentrations in male twins. Am J Clin Nutr 92:1393-1398.

5. Arguelles LM, Langman CB, Ariza AJ, Ali FN, Dilley K, et al. (2009) Heritability and environmental factors 
affecting vitamin D status in rural Chinese adolescent twins. J Clin Endocrinol Metab 94:3273-3281.

6. Snellman G, Melhus H, Gedeborg R, Olofsson S, Wolk A, et al. (2009) Seasonal genetic influence on serum 25-hydroxyvitamin D levels: a twin study. PLoS One 4:e7747.

7. Bu FX, Armas L, Lappe J, Zhou Y, Gao G, et al. (2010) Comprehensive association analysis of nine candidate genes with serum 25-hydroxy vitamin D levels among healthy Caucasian subjects. Hum Genet 128:549-556.

8. Engelman CD, Fingerlin TE, Langefeld CD, Hicks PJ, Rich SS, et al. (2008) Genetic and environmental determinants of 25-hydroxyvitamin D and 1,25-dihydroxyvitamin D levels in Hispanic and African Americans. $J$ Clin Endocrinol Metab 93:3381-3388.

9. Sinotte M, Diorio C, Bérubé S, Pollak M, Brisson J (2009) Genetic polymorphisms of the vitamin D binding protein and plasma concentrations of 25-hydroxyvitamin D in premenopausal women. Am J Clin Nutr 89:634-640.

10. McGrath JJ, Saha S, Burne TH, Eyles DW (2010) A systematic review of the association between common single nucleotide polymorphisms and 25-hydroxyvitamin D concentrations. J Steroid Biochem Mol Biol 121:471477.

11. Ahn J, Yu K, Stolzenberg-Solomon R, Simon KC, McCullough ML, et al. (2010) Genome-wide association study of circulating vitamin D levels. Hum Mol Genet 19:2739-2745.

12. Wang TJ, Zhang F, Richards JB, Kestenbaum B, van Meurs JB, et al. (2010) Common genetic determinants of vitamin D insufficiency: a genome-wide association study. Lancet 376:180-188.

13. Cooper JD, Smyth DJ, Walker NM, Stevens H, Burren OS, et al. (2011) Inherited variation in vitamin D genes is associated with predisposition to autoimmune disease type 1 diabetes. Diabetes 60:1624-1631.

14. Lu L, Sheng H, Li H, Gan W, Liu C, et al. (2012) Associations between common variants in $\mathrm{GC}$ and DHCR7/NADSYN1 and vitamin D concentration in Chinese Hans. Hum Genet 131:505-512.

15. Ahn J, Albanes D, Berndt SI, Peters U, Chatterjee N, et al. (2009) Vitamin D-related genes, serum vitamin D concentrations and prostate cancer risk. Carcinogenesis 30:769-776.

16. Wjst M, Altmüller J, Faus-Kessler T, Braig C, Bahnweg M, et al. (2006) Asthma families show transmission disequilibrium of gene variants in the vitamin D metabolism and signalling pathway. Respir Res 7:60.

17. Ramos-Lopez E, Kahles H, Weber S, Kukic A, PennaMartinez M, et al. (2008) Gestational diabetes mellitus and vitamin D deficiency: genetic contribution of CYP27B1 and CYP2R1 polymorphisms. Diabetes Obes Metab 10:683-685.

18. Orton SM, Morris AP, Herrera BM, Ramagopalan SV,
Lincoln MR, et al. (2008) Evidence for genetic regulation of vitamin D status in twins with multiple sclerosis. Am J Clin Nutr 88:441-447.

19. Hyppönen E, Berry DJ, Wjst M, Power C (2009) Serum 25-hydroxyvitamin D and IgE - a significant but nonlinear relationship. Allergy 64:613-620.

20. d'Alésio A, Garabédian M, Sabatier JP, GuaydierSouquières G, Marcelli C, et al. (2005) Two single-nucleotide polymorphisms in the human vitamin D receptor promoter change protein-DNA complex formation and are associated with height and vitamin D status in adolescent girls. Hum Mol Genet 14:3539-3548.

21. Gennari L, Becherini L, Falchetti A, Masi L, Massart F, et al. (2002) Genetics of osteoporosis: role of steroid hormone receptor gene polymorphisms. J Steroid Biochem Mol Biol 81:1-24.

22. Valdivielso JM, Fernandez E (2006) Vitamin D receptor polymorphisms and diseases. Clin Chim Acta 371:1-12.

23. Michaëlsson K, Wolk A, Jacobsson A, Kindmark A, Grundberg E, et al. (2006) The positive effect of dietary vitamin $\mathrm{D}$ intake on bone mineral density in men is modulated by the polyadenosine repeat polymorphism of the vitamin D receptor. Bone 39:1343-1351.

24. Langdahl BL, Gravholt $\mathrm{CH}$, Brixen $\mathrm{K}$, Eriksen EF (2000) Polymorphisms in the vitamin D receptor gene and bone mass, bone turnover and osteoporotic fractures. Eur J Clin Invest 30:608-617.

25. Cheng JB, Levine MA, Bell NH, Mangelsdorf DJ, Russell DW (2004) Genetic evidence that the human CYP2R1 enzyme is a key vitamin D 25-hydroxylase. Proc Natl Acad Sci US A 101:7711-7715.

26. Morrison NA, Yeoman R, Kelly PJ, Eisman JA (1992) Contribution of trans-acting factor alleles to normal physiological variability: vitamin D receptor gene polymorphism and circulating osteocalcin. Proc Natl Acad Sci U S A 89:6665-6669.

27. Motohashi Y, Yamada S, Yanagawa T, Maruyama T, Suzuki R, et al. (2003) Vitamin D receptor gene polymorphism affects onset pattern of type 1 diabetes. J Clin Endocrinol Metab 88:3137-3140.

28. Shimada A, Kanazawa Y, Motohashi Y, Yamada S, Maruyama T, et al. (2008) Evidence for association between vitamin $\mathrm{D}$ receptor BsmI polymorphism and type 1 diabetes in Japanese. J Autoimmun 30:207-211.

29. Watanabe M, Fukutome K, Murata M, Uemura H, Kubota Y, et al. (1999) Significance of vitamin D receptor gene polymorphism for prostate cancer risk in Japanese. Anticancer Res 19:4511-4514.

30. Ponsonby AL, Pezic A, Ellis J, Morley R, Cameron F, et al. (2008) Variation in associations between allelic variants of the vitamin D receptor gene and onset of type 1 diabetes mellitus by ambient winter ultraviolet radiation levels: a meta-regression analysis. Am J Epidemiol 168:358-365. 
31. Martineau AR, Timms PM, Bothamley GH, Hanifa Y, Islam K, et al. (2011) High-dose vitamin D(3) during intensive-phase antimicrobial treatment of pulmonary tuberculosis: a double-blind randomised controlled trial. Lancet 377:242-250.

32. Wishart JM, Horowitz M, Need AG, Scopacasa F, Morris HA, et al. (1997) Relations between calcium intake, calcitriol, polymorphisms of the vitamin D receptor gene, and calcium absorption in premenopausal women. Am J Clin Nutr 65:798-802.

33. Whitfield GK, Remus LS, Jurutka PW, Zitzer H, Oza AK, et al. (2001) Functionally relevant polymorphisms in the human nuclear vitamin D receptor gene. Mol Cell Endocrinol 177:145-159.

34. Ogunkolade BW, Boucher BJ, Prahl JM, Bustin SA, Burrin JM, et al. (2002) Vitamin D receptor (VDR) mRNA and VDR protein levels in relation to vitamin D status, insulin secretory capacity, and VDR genotype in Bangladeshi Asians. Diabetes 51:2294-2300.

35. Morrison NA, Qi JC, Tokita A, Kelly PJ, Crofts L, et al. (1994) Prediction of bone density from vitamin D receptor alleles. Nature 367:284-287.

36. Thakkinstian A, D'Este C, Attia J (2004) Haplotype analysis of VDR gene polymorphisms: a meta-analysis. Osteoporos Int 15:729-734.

37. Thakkinstian A, D'Este C, Eisman J, Nguyen T, Attia J (2004) Meta-analysis of molecular association studies: vitamin D receptor gene polymorphisms and BMD as a case study. J Bone Miner Res 19:419-428.

38. Niino M, Fukazawa T, Yabe I, Kikuchi S, Sasaki H, et al. (2000) Vitamin D receptor gene polymorphism in multiple sclerosis and the association with HLA class II alleles. J Neurol Sci 177:65-71.

39. Holick MF (2011) Vitamin D deficiency in 2010: health benefits of vitamin D and sunlight: a D-bate. Nat Rev Endocrinol 7:73-75.

40. Baroncelli GI, Bereket A, El Kholy M, Audì L, Cesur Y, et al. (2008) Rickets in the Middle East: role of environment and genetic predisposition. J Clin Endocrinol Metab 93:1743-1750.

41. Kaneko A, Urnaa V, Nakamura K, Kizuki M, Seino K, et al. 2007 Vitamin D receptor polymorphism among rickets children in Mongolia. J Epidemiol 17:25-29.

42. Fischer PR, Thacher TD, Pettifor JM, Jorde LB, Eccleshall TR, et al. (2000) Vitamin D receptor polymorphisms and nutritional rickets in Nigerian children. J Bone Miner Res 15:2206-2210.

43. Bora G, Ozkan B, Dayangaç-Erden D, Erdem-Yurter H, Coşkun T (2008) Vitamin D receptor gene polymorphisms in Turkish children with vitamin D deficient rickets. Turk J Pediatr 50:30-33.

44. Ak DG, Kahraman H, Dursun E, Duman BS, Erensoy N, et al. (2005) Polymorphisms at the ligand binding site of the vitamin D receptor gene and osteomalacia. Dis Markers 21:191-197.

45. Misra M, Pacaud D, Petryk A, Collett-Solberg PF, Kappy M, et al. (2008) Vitamin D deficiency in children and its management: review of current knowledge and recommendations. Pediatrics 122:398-417.

46. Schlingmann KP, Kaufmann M, Weber S, Irwin A, Goos C, et al. (2011) Mutations in CYP24A1 and idiopathic infantile hypercalcemia. $N$ Engl J Med 365:410-421. 